\title{
HUBUNGAN PERILAKU HIDUP BERSIH DAN SEHAT (PHBS) IBU DENGAN KEJADIAN DIARE DI PUSKESMAS GARUDA PEKANBARU
}

\author{
Isnaniar, Yuni Indri Lestari \\ Program Studi D-III Keperawatan Universitas Muhammadiyah Riau \\ e-mail:isnaniar@umri.ac.id,yuniindrilestari@umri.ac.id
}

\begin{abstract}
ABSTRAK
Diare masih merupakan salah satu masalah kesehatan masyarakat di Indonesia. Diare didefinisikan sebagai perubahan konsistensi feses dan perubahan frekuensi buang air besar lebih dari 3 kali dalam sehari. Salah satu penyebab dari terjadinya diare adalah faktor lingkungan dan perilaku. Penerapan perilaku hidup bersih dan sehat (PHBS) pada bayi tergantung kepada perilaku hidup bersih dan sehat ibu, karena bayi masih tidak bisa melakukan segala sesuatu dengan sendiri (Mardta, 2014). Tujuan penelitian adalah untuk mengetahui "Hubungan Perilaku Hidup Bersih Dan Sehat (PHBS) ibu dengan kejadian diare pada bayi di Puskesmas Garuda Pekanbaru”. Jenis penelitian yang digunakan adalah cross sectional study dengan tehnik pengambilan sampel accidental sampling yang berjumlah 33 responden. Alat pengumpulan data menggunakan kuesioner dan Analisa Data yang digunakan adalah univariate dan bivariat. Hasil Penelitian yang telah dilaksanakan pada tanggal 21- 28 febuari 2017 menunjukkan bahwa terdapat hubungan antara perilaku memberikan ASI eklusif dengan kejadian diare pada bayi, nilai $\mathrm{P}=0,007$. Tidak terdapat hubungan menggunakan air bersih dengan kejadian diare pada bayi, nilai $\mathrm{p}=0,805$. Terdapat hubungan antara mencuci tangan dengan air bersih dan sabun dengan kejadian diare pada bayi nilai $\mathrm{P}=0,000$. Tidak terdapat hubungan antara menggunakan jamban dengan kejadian diare pada bayi, $p=0,183$ Dan Berdasarkan hasil penelitian tersebut diharapkan kepada pihak ibu untuk dapat menerapkan perilaku hidup bersih dan sehat untuk mencegah terjadinya diare pada bayi.
\end{abstract}

Kata kunci: Perilaku Hidup Bersih dan Sehat (PHBS) ibu, Diare.

\section{PENDAHULUAN}

Menurut data WHO tahun 2008, Penyakit diare merupakan salah satu penyebab utama kesakitan dan kematian hampir di seluruh negara. Semua kelompok usia bisa terkena diare, tetapi penyakit diare dalam tingkat berat dengan risiko kematian yang tinggi terutama terjadi pada bayi dan balita. (Wulandari, 2009, dalam Wijaya, 2012).

Bayi lebih rentan mengalami dehidrasi karena sulit untuk diberi cairan melalui mulut dibandingkan dengan kelompok usia lainnya, selain itu komposisi cairan tubuh pada bayi relatif besar yaitu sekitar $80-85 \%$ berat badan dan pada anak usia $>1$ tahun mengandung air sebanyak 70$75 \%$. Kehilangan cairan tubuh sebanyak $10 \%$ pada bayi dapat mengakibatkan kematian setelah sakit selama 2-3 hari (Widjaja, 2002, dalam Mardta, 2014).

Menurut Depkes RI tahun 2006 Perilaku hidup bersih dan sehat (PHBS) pada hakikatnya merupakan perilaku pencegahan oleh individu atau keluarga dari berbagai penyakit (Jayanti at al, 2011).

Dalam Depertemen Kesehatan RI tahun 2009 mengatakan Penerapan perilaku hidup bersih dan sehat pada bayi tergantung kepada perilaku hidup bersih dan sehat ibu, karena bayi masih tidak bisa melakukan segala sesuatu dengan sendiri. Perilaku higienis yang disurvey dalam Riskesdas (Riset Kesehatan Dasar) tahun 2007 meliputi pemberian ASI eksklusif, kebiasaan buang air besar (BAB) dan kebiasaan mencuci tangan. Perilaku BAB yang benar adalah bila ibu melakukannya di jamban dan mencuci tangan yang benar adalah bila ibu mencuci tangan dengan sabun sebelum makan, sebelum menyiapkan makanan, setelah buang air besar, setelah menceboki bayi/anak dan setelah memegang binatang (Mardta, 2014).

Menurut Riskesdas 2013 Secara nasional, penduduk yang telah memenuhi kriteria PHBS baik sebesar $38,7 \%$. Terdapat lima provinsi dengan pencapaian PHBS rendah berturut-turut yaitu Papua (24,4\%), Nusa Tenggara Timur $(26,8 \%)$, Gorontalo $(27,8 \%)$, Sumatera Barat $(28,2 \%)$ dan Riau (28,1\%) (Kusumasari, 2015).

. Berdasarkan data dari dinas kesehatan kota Pekanbaru tahun 2015 total penderita diare pada bayi di puskesmas Garuda adalah sebanyak 76 bayi, dan menjadi puskesmas dengan angka 
kejadian diare tetinggi pada bayi di kota Pekanbaru.

Hasil penelitian Survey Awal yang telah dilakukan oleh peneliti tanggal 19 Desember - 21 Desember 2016 di Puskesmas Garuda Pekanbaru didapatkan dari 10 orang ibu yang membawa bayi, 6 orang ibu mengatakan bayinya pernah mengalami diare dalam 6 bulan terakhir.

Data dari Puskesmas Garuda Pekanbaru, bayi yang mengalami diare dalam 6 bulan terakhir yaitu dari bulan Mei sampai bulan Oktober 2016 adalah sebanyak 33 bayi.

Berdasarkan uraian di atas, peneliti tertarik untuk melakukan penelitian yang berjudul "Hubungan Perilaku Hidup Bersih dan Sehat (PHBS) Ibu dengan Kejadian Diare pada Bayi di Puskesmas Garuda Pekanbaru".

\section{METODOLOGI PENELITIAN}

Desain penelitian ini adalah cross Sectional study, desain ini merupakan rancangan penelitian yang pengukuran atau pengamatannya di lakukan secara simultan pada satu saat (sekali waktu). Penelitian melakukan pengukuran atau pengamatan tentang hubungan perilaku hidup bersih dan sehat ibu dengan kejadian diare pada bayi (Chandra, 2008 ).

Teknik pengambilan sampel yaitu Accidental Sampling dimana dilakukan dengan cara kebetulan bertemu.

Pengolahan dan analisis data pada penelitian ini dilakukan dengan menggunakan alat bantu komputer dengan program SPSS for windows release 17.0. Data yang terkumpul diolah secara univariat untuk melihat deskripsi dari karakteristik responden dan bivariat dengan uji Chi Square menggunakan tabel $2 \times 2$ untuk mengetahui faktor risiko yang mempengaruhi variabel terikat.

\section{HASIL DAN PEMBAHASAN}

Penelitian yang dilakukan pada tanggal 2128 Februari 2017 terhadap 33 responden dengan menggunakan kuesioner untuk mengetahui hubungan antara perilaku hidup bersih dan sehat (PHBS) ibu dengan kejadian diare pada bayi di Puskesmas Garuda Pekanbaru dapat dilihat pada tabel-tabel sebagai berikut:
Tabel .1

Distribusi Frekuensi Umur Ibu di Puskesmas Garuda Pekanbaru Februari 2017

\begin{tabular}{lllll}
\hline No & $\begin{array}{l}\text { Ketagori Umur } \\
\text { (Tahun) }\end{array}$ & \multicolumn{1}{c}{$\begin{array}{c}\text { Frekuensi } \\
(\mathbf{f})\end{array}$} & $\begin{array}{c}\text { Persentase } \\
(\%)\end{array}$ \\
\hline 1 & $\begin{array}{l}\text { Dewasa } \\
\text { (17-35) }\end{array}$ & Awal & $\mathbf{3 2}$ & $\mathbf{9 7 , 0} \%$ \\
2 & $\begin{array}{l}\text { Dewasa } \\
(36-54)\end{array}$ & Tengah & 1 & $3,0 \%$ \\
\hline & Total & $\mathbf{3 3}$ & $\mathbf{1 0 0}$
\end{tabular}

Tabel 2

Distribusi Frekuensi Tingkat Pendidikan Ibu di Puskesmas Garuda Pekanbaru Februari 2017

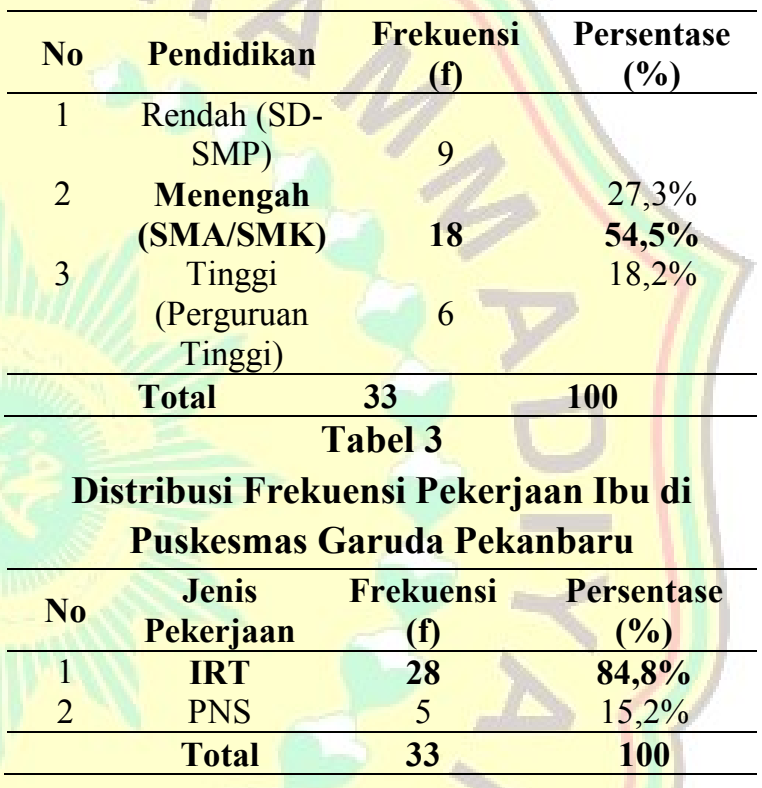

Tabel 4

Distribusi Frekuensi Ibu Mendapatkan Informasi Diare di Puskesmas Garuda Pekanbaru

\begin{tabular}{cccc}
\hline No & $\begin{array}{c}\text { Informasi } \\
\text { Diare }\end{array}$ & $\begin{array}{c}\text { Frekuensi } \\
\text { (f) }\end{array}$ & $\begin{array}{c}\text { Persentase } \\
(\mathbf{\%})\end{array}$ \\
\hline 1 & Ya & $\mathbf{1 7}$ & $\mathbf{5 1 , 5 \%}$ \\
2 & Tidak & 16 & $48,5 \%$ \\
\hline & Total & $\mathbf{3 3}$ & $\mathbf{1 0 0}$ \\
\hline
\end{tabular}

Tabel 5

Distribusi Frekuensi Sumber Informasi

\begin{tabular}{cccc}
\hline No & $\begin{array}{c}\text { Sumber } \\
\text { Informasi }\end{array}$ & $\begin{array}{c}\text { Frekuensi } \\
\text { (f) }\end{array}$ & $\begin{array}{c}\text { Persentase } \\
(\mathbf{\%})\end{array}$ \\
\hline 1 & Media & 3 & $9,1 \%$ \\
2 & Cetak & 4 & $12,1 \%$ \\
& Media & 1 & $3,0 \%$ \\
3 & Elektronik & & \\
$\mathbf{4}$ & Teman & $\mathbf{9}$ & $\mathbf{2 7 , 3 \%}$ \\
\hline
\end{tabular}




\begin{tabular}{ccc}
\hline 5 & Tenaga & \\
Kesehatan \\
Tidak \\
$\begin{array}{c}\text { Mendapat } \\
\text { nformasi }\end{array}$ & 16 & $48,5 \%$ \\
\hline Total & $\mathbf{3 3}$ & $\mathbf{1 0 0}$ \\
\hline & Tabel 6
\end{tabular}

Distribusi Frekuensi Bayi ibu yang Pernah Mengalami Diare Dalam 6 Bulan Terakhir di Puskesmas Garuda Pekanbru Februari 2017

\begin{tabular}{cccc}
\hline No & $\begin{array}{c}\text { Pernah } \\
\text { Mengalami } \\
\text { Diare }\end{array}$ & $\begin{array}{c}\text { Frekuensi } \\
\text { (f) }\end{array}$ & $\begin{array}{c}\text { Persentase } \\
\mathbf{( \% )}\end{array}$ \\
\hline 1 & Ya & $\mathbf{1 8}$ & $\mathbf{5 4 , 5 \%}$ \\
2 & Tidak & 15 & $45,5 \%$ \\
\hline & Total & $\mathbf{3 3}$ & $\mathbf{1 0 0}$ \\
\hline
\end{tabular}

Tabel 7

Distribusi Frekuensi Berapa lama Bayi

Mengalami Diare di Puskesmas Garuda Pekanbru Februari 2017

\begin{tabular}{cccc}
\hline No & $\begin{array}{c}\text { Pernah } \\
\text { Mengalami } \\
\text { Diare }\end{array}$ & $\begin{array}{c}\text { Frekuensi } \\
\text { (f) }\end{array}$ & $\begin{array}{c}\text { Persentase } \\
(\%)\end{array}$ \\
\hline 1 & $<$ hari & $\mathbf{1 5}$ & $\mathbf{8 3 , 3 3 \%}$ \\
2 & $\begin{array}{c}>3 \text { hari } \\
16,67 \%\end{array}$ & $\mathbf{1 0 0}$ \\
\hline & Total & $\mathbf{1 8}$ & \\
\hline
\end{tabular}

Tabel 8

Distribusi Frekuensi PHBS Ibu di Puskesmas Garuda Pekanbru Februari 2017

\begin{tabular}{|c|c|c|c|}
\hline Variabel & Kategori & $\begin{array}{l}\text { jumla } \\
\text { h (n) }\end{array}$ & $\begin{array}{l}\text { Persentas } \\
\text { e \% }\end{array}$ \\
\hline \multirow{2}{*}{$\begin{array}{l}\text { perilku } \\
\text { memberi } \\
\text { ASI eklusif }\end{array}$} & Baik & 23 & 69,7 \\
\hline & Tidak Baik & 10 & 30,3 \\
\hline \multirow{2}{*}{$\begin{array}{l}\text { Perilku } \\
\text { menggunaka } \\
\text { n air bersih }\end{array}$} & Baik & 27 & 81,8 \\
\hline & Tidak Baik & 6 & 18,2 \\
\hline \multirow{2}{*}{$\begin{array}{l}\text { Perilaku } \\
\text { mencuci } \\
\text { tangan }\end{array}$} & Baik & 18 & 54,5 \\
\hline & Tidak Baik & 15 & 45,5 \\
\hline \multirow{2}{*}{$\begin{array}{l}\text { perilaku } \\
\text { menggunkan } \\
\text { jamban sehat }\end{array}$} & Baik & 31 & 93,9 \\
\hline & Tidak Baik & 2 & 6,1 \\
\hline
\end{tabular}

\section{Tabel 9}

Distribusi Frekuensi Hubungan Perilaku Ibu Memberi ASI Eklusif Dengan Kejadian Diare Pada Bayi di Puskesmas Garuda Pekanbaru

\begin{tabular}{|c|c|c|c|c|c|c|c|c|}
\hline \multirow{2}{*}{\multicolumn{2}{|c|}{ PHBS IBU }} & \multicolumn{7}{|c|}{ Kejadian Diare Pada Bayi dalam 6 Bulan Terakhir } \\
\hline & & Tidak & $\%$ & Ya & $\%$ & Total & $\%$ & pvalue \\
\hline \multirow{2}{*}{$\begin{array}{l}\text { Perilaku } \\
\text { Pemberian } \\
\text { ASI } \\
\text { Eklusif }\end{array}$} & Baik & 14 & 60,87 & 9 & 39,13 & 23 & 100 & \multirow[b]{2}{*}{0,007} \\
\hline & $\begin{array}{l}\text { Tidak } \\
\text { Baik }\end{array}$ & 1 & 10,00 & 9 & 90,00 & 10 & 100 & \\
\hline Total & & 15 & 45,45 & 18 & 54,55 & 33 & 100 & \\
\hline
\end{tabular}

Tabel 10

Distribusi Frekuensi Hubungan Perilaku Ibu Menggunakan Air Bersih Dengan Kejadian Diare Pada Bayi di Puskesmas Garuda Pekanbaru

\begin{tabular}{|c|c|c|c|c|c|c|c|c|}
\hline \multirow{2}{*}{\multicolumn{2}{|c|}{ PHBS IBU }} & \multicolumn{7}{|c|}{ Kejadian Diare Pada Bại dalam 6 Bulan Terakhir } \\
\hline & & Tidak & $\%$ & Ya & $\%$ & Total & $\%$ & Pvalue \\
\hline \multirow{3}{*}{\begin{tabular}{|l} 
Perilaku \\
menggunakan \\
air bersih
\end{tabular}} & Baik & 12 & 44,44 & 15 & 55,56 & 27 & 100 & \multirow{3}{*}{0,805} \\
\hline & Tidak & & & & & & & \\
\hline & Baik & 3 & 50,00 & 3 & 50,00 & 6 & 100 & \\
\hline \multicolumn{2}{|l|}{ Total } & 15 & 45,45 & 18 & 54,55 & 33 & 100 & \\
\hline
\end{tabular}

Tabel 11

Distribusi Frekuensi Hubungan Perilaku Ibu Mencuci Tangan Menggunakan Air Bersih dan Sabun Dengan Kejadian Diare Pada Bayi di Puskesmas Garuda Pekanbaru

\begin{tabular}{|c|c|c|c|c|c|c|c|c|}
\hline \multirow{2}{*}{ PHBS IBI } & & \multicolumn{7}{|c|}{ Kejadian Diare Pada Bayi dalam 6 Bulan Terakhir } \\
\hline & & Tidak & $\%$ & $\mathrm{Ya}$ & $\%$ & Total & $\%$ & Pvalue \\
\hline $\begin{array}{l}\text { Perilaku cuci } \\
\text { tangan }\end{array}$ & Baik & 15 & 83,33 & 3 & 16,67 & 18 & 100 & \\
\hline $\begin{array}{l}\text { menggunakan } \\
\text { air bersih dan } \\
\text { sabun }\end{array}$ & $\begin{array}{l}\text { Tidak } \\
\text { Baik }\end{array}$ & 0 & 0,00 & 15 & 100,00 & 15 & 100 & 0,000 \\
\hline Total & & 15 & 45,45 & 18 & 54,55 & 33 & 100 & \\
\hline
\end{tabular}

Distribusi Frekuensi Hubungan Perilaku Ibu Menggunkan Jamban Sehat Dengan Kejadian Diare Pada Bayi di Puskesmas Garuda Pekanbaru

\begin{tabular}{|c|c|c|c|c|c|c|c|c|}
\hline \multirow{2}{*}{\multicolumn{2}{|c|}{ PHBS IBU }} & \multicolumn{7}{|c|}{ Kejadian Diare Pada Bayi dalam 6 Bulan Terakhir } \\
\hline & & Tidak & $\%$ & Ya & $\%$ & Total & $\%$ & Pvalue \\
\hline \multirow{2}{*}{$\begin{array}{l}\text { Perilaku } \\
\text { menggunakan } \\
\text { jamban }\end{array}$} & Baik & 15 & 83,33 & 16 & 88,89 & 18 & 31 & \multirow{3}{*}{0,183} \\
\hline & $\begin{array}{l}\text { Tidak } \\
\text { Baik }\end{array}$ & 0 & 0,00 & 2 & 13,33 & 15 & 2 & \\
\hline Total & & 15 & 45,45 & 18 & 54,55 & 33 & 100 & \\
\hline
\end{tabular}

Bedasarkan hasil penelitian yang dilakukan peneliti pada bulan Februari 2017 di Puskesmas 
Garuda Pekanbaru dengan judul "Hubungan Perilaku Hidup Bersih dan Sehat (PHBS) Ibu Dengan Kejadian Diare Pada Bayi', di dapatkan hasil dari 33 bayi 18 (54,5\%) mengalami diare dalam 6 bulan terakhir, hal ini dapat disebabkan oleh perilaku hidup bersih dan sehat (PHBS) ibu.

1. Hubungan Perilaku Hidup Bersih dan Sehat (PHBS) Ibu Memberikan ASI Eklusif dengan Kejadian Diare Pada Bayi

Menurut hasil yang diperoleh dari penelitian ini dari $10 \mathrm{ibu}$ yang berperilaku tidak baik dalam memberikan ASI eklusif didapatkan $9(90,00 \%)$ bayi mengalami diare, dan terdapat hubungan yang signifikan antara perilaku ibu memberi ASI eklusif dengan kejadian diare pada bayi, yang dibuktikan dengan nilai $\mathrm{P}$ - value $<0,05$ yaitu 0,007 .

Hasil penelitian diatas sesuai dengan penelitian yang dilakukan oleh Eka Ramadhani dan Gustina Lubis (2012), didapatkan bahwa terdapat hubungan yang signifikan antara perilaku mememberikan ASI Eklusif Dengan Kejadian diare akut pada bayi $\mathrm{p}=0,001$.

Pada waktu lahir sampai beberapa bulan sesudahnya, bayi belum dapat membentuk kekebalan sendiri secara sempurna. ASI merupakan substansi bahan yang hidup dengan kompleksitas biologis yang luas yang mampu memberikan daya perlindungan, baik secara aktif maupun melalui pengaturan imunologis. (Soetjaningsih 2001, dalam Wijayanti 2010).

Menghentikan ASI eklusif dan perilaku ibu yang tidak baik dalam memberikan ASI dapat menyebabkan bayi mengalami diare. Untuk mencegah diare pada bayi selain memberikan ASI Eklusif, ibu juga perlu memperhatikan perilaku dalam memberikan ASI tersebut.

2. Hubungan Perilaku Hidup Bersih dan Sehat (PHBS) Ibu Menggunakan Air Bersih dengan Kejadian Diare Pada Bayi

Berdasarkan hasil penelitian yang telah dilakukan tidak terdapat hubungan yang signifikan antara perilaku ibu menggunakan air bersih dengan kejadian diare pada bayi, yang dibuktikan dengan nilai $\mathrm{P}$ - value $>0,05$ yaitu 0,805 .

Dari hasil penelitian yang dilakukan oleh Mila Falasifa (2015), juga tidak ditemukan hubungan antara pengelolaan menggunakan air bersih dengan kejadian diare, nilai $\mathrm{p}=0,024$.

Tidak adanya hubungan antara menggunakan air bersih dengan kejadian diare dikarenakan penyakit diare merupakan salah satu penyakit yang penyebabnya multifactor, salah satunya bisa disebabkan karena perilaku cuci tangan pakai sabun (CTPS) yang masih buruk (Falasifa, 2015).

3. Hubungan Perilaku Hidup Bersih dan Sehat (PHBS) Ibu Mencuci Tangan dengan Air Bersih dengan Kejadian Diare Pada Bayi

Berdasarkan hasil penelitian yang telah dilakukan terdapat hubungan Mencuci Tangan dengan Air Bersih dan Sabun dengan kejadian diare pada bayi, dari 15 ibu yang berperilaku tidak baik dalam mencuci tangan menggunakan air bersih dan sabun di dapatkan secara keseluruhan $15(100 \%)$ bayi mengalami diare, dan berdasarkan statistik terdapat hubungan yang signifikan antara perilaku mencuci tangan menggunakan air bersih dan sabun dengan kejadian diare pada bayi, yang dibuktikan dengan nilai $\mathrm{P}$ - value $<0,05$ yaitu 0,000 .

Hasil penelitian diatas sesuai dengan penelitian yang dilakukan oleh Yuni Suryaningtyas (2016), dari 83 ibu yang tidak mencuci tangan menggunakan sabun 59 (71\%) bayi dengan nilai $\mathrm{p}=0,003$.

Zuliana (2016) yang menyatakan bahwa mencuci tangan yang baik dan benar menggunakan sabun dapat menurunkan angka kejadian diare sebesar $47 \%$. Perilaku cuci tangan yang baik dan benar adalah dengan menggunakan sabun dan air menggalir yang dapat menghentikan kuman yang masuk kedalam tubuh.

4. Hubungan Perilaku Hidup Bersih dan Sehat (PHBS) Ibu Menggunakan Jamban dengan Kejadian Diare Pada Bayi

Berdasarkan hasil penelitian yang telah dilakukan dari dari 15 ibu yang berperilaku tidak baik dalam menggunakan jamban di dapatkan 2 $(13,33 \%)$ bayi mengalami diare, dan berdasarkan statistik tidak terdapat hubungan yang signifikan antara perilaku ibu menggunakan jamban sehat dengan kejadian diare pada bayi, yang dibuktikan dengan nilai $\mathrm{P}$ - value $>0,05$ yaitu 0,183 
Hal ini berbeda dengan penelitian yang dilakukan oleh Fajriana Ayu (2012) didapatkan data bahwa terdapat hubungan yang signifikan antara menggunakan jamban yang sehat dengan kejadian diare pada balita dengan nilai $\mathrm{p}=0,000$,

Tidak adanya hubungan antara menggunakan jamban sehat dengan kejadian diare pada bayi karena diare merupakan salah satu penyakit yang penyebabnya memiliki banyak faktor penyebab, yang berarti tidak hanya dapat disebabkan oleh penggunaan jamban tetapi juga dapat di sebabkan oleh pemberian ASI eklusif maupun perilaku dalam mencuci tangan menggunakan air bersih dan sabun.

\section{KESIMPULAN}

Berdasarkan hasil penelitian yang dilakukan di Puskesmas Garuda Pekanbaru pada tanggal 2128 Februari 2017 dengan cara menyebarkan kuisioner yang berisikan pernyataan dari 4 indikator PHBS ibu meliputi pemberian ASI eklusif, air bersih, mencuci tangan dengan air dan sabun, serta penggunaan jamban sehat maka dapat disimpulkan bahwa :

1. Terdapat hubungan antara perilaku ibu memberi ASI eklusif dengan kejadian diare pada bayi.

2. Tidak terdapat hubungan antara perilaku ibu menggunakan air bersih dengan kejadian diare pada bayi.

3. Terdapat hubungan antara perilaku mencuci tangan menggunakan air bersih dan sabun dengan kejadian diare pada bayi.

Tidak terdapat hubungan antara perilaku ibu menggunakan jamban sehat dengan kejadian diare pada bayi

\section{DAFTAR PUSTAKA}

Amaliah, Siti. (2010). Hubungan Sanitasi Lingkungan dan Faktor Budaya Dengan Kejadian Diare Pada Anak Balita di Desa Toriyo Kecamatan Bendosari Kabupaten Sukoharjo. Jurnal Penelitian.

Arief, Z.R \& Weni, K.S. (200). Neonatus \& Asuhan Keperawatan Anak Cetakan pertama. Yogyakarta: Nuha Medika.
Candra, Budiman. (2008). Metodologi Penelitian Kesehatan. Jakarta: Penerbit Buku Kedokteran EGC.

Eka, Ramadhani \& Gustina Lubis. (2012). Hubungan Pemberian ASI Eksklusif dengan Angka Kejadian Diare Akut pada Bayi Usia 0-1 Tahun di Puskesmas Kuranji Kota Padang. Jurnal Kesehatan Andalas.

Fajriana, Ayu Rahmawati. (2012). Hubungan Kepemilikan Jamban Dengan Kejadian Diare Pada Balita di Desa Jatisobo Kecamatan Polokarto Kabupaten Sukoharjo. Universitas muhammadiyah surakarta

Hamzah B., Arsunan Asin, \& Jumriani Ansar. (2012). Hubungan Perilaku Hidup Bersih dan Sehat Dengan Kejadian Diare Pada Balita di Kecamatan Belawa Kabupaten Kampar. Jurnal Penelitian.

Hidayat. A.A.A. (2007). Metode Penelitian Keperawatan dan Tekhnik Analisa Data. Jakarta: Salemba Medika

Jayanti, Linda Dwi., Yekti Hartati \& Dadang Sukandar. (2011). Perilaku Hidup Bersih dan Sehat (PHBS) Serta Perilaku Gizi Seimbang Ibu Kaitannya Dengan Status Gizi dan Kesehatan Balita di Kabupaten Bojonegoro, Jawa Timur. Jurnal Gizi dan Pangan

Kusumasasi, Ratna Diani. (2015). Hubungan Perilaku Hidup Bersih dan Sehat Ibu Dengan Kejadian Diare Pada Usia 3 bulan-2 tahun di Desa Pulosari Kecamatan Kebakramat Kabupaten Karanganyar. Naskah Publikasi. Universitas Muhammadiyah Surakarta

Mardta, Ronny. (2015). Hubungan Antara Perilaku Hidup Bersih dan Sehat (PHBS) Ibu Dengan Kejadian Diare Pada Bayi Usia 1-18 Bulan di Kelurahan Campago Ipuh Kabupaten Mandiangin. Stikes Perintis Sumatera Barat.

Maulana, H.D.J. (2009). Promosi Kesehatan. Jakarta: EGC

Mila Falasifa (2015) Hubungan Antara Sanitasi Total Dengan Kejadian Diare Pada Balita di Wilayah Kerja Puskesmas Kepil 
2 Kecamatan Kepil Kabupaten Wonosobo. Universitas Negeri Semarang Notoadmodjo, Soekidjo. (2005). Metodogi Penelitian Kesehatan. Edisi Revisi., Jakarta: PT. Rineka Cipta.

Nurhajati, Nunun (2015). Perilaku Hidup Bersih dan Sehat (PHBS) Masyarakat Desa Samir Dalam Meningkatkan Kesehatan Masyarakat. Jurnal Penelitian

Setiadi. (2007). Konsep dan Penulisan Riset Keperawatan. Yogyakarta: Graha Ilmu.

Sunoto et al.(1999). Pendidikan Medik Pemberantasan Diare: Buku Ajar Diare.Jakarta:Departemen Kesehatan R.I Ditjen PPM\&PLP

Suradi, Rulina. (2008). "Manfaat ASI dan Menyusui". Jakarta: Fakultas Kedokteran Universitas Indonesia Syafrudin \& Hamidah. 2007. Kebidanan Komunitas. Jakarta:EGC.

Wiharto, M. Hilmy Reza. 2015. Hubungan Perilaku hidup bersih dan Sehat Dengan Kejadian Diare Pada Tatanan Rumah Tangga Di Daerah Kedaung Wetan Tanggerang. Jakarta. Jurnal Universitas Esa Unggul

Wijayanti W. (2010). "Hubungan antara pemberian asi eksklusif dengan angka Kejadian diare pada bayi umur 0-6 bulan di puskesmas Gilingan kecamatan banjarsari surakarta". Universitas Sebelas Maret.
Widjaja. (2002). "Mengatasi Diare Dan Keracunan Pada Balita". Jakarta: PT Kawan Pustaka

Wijaya Y. (2012). "Faktor Resiko Kejadian Diare Pada Balita. Jurnal Penelitian . 2011. Hubungan PHBS Dengam Kejadian Diare di Desa Pardede onan Kecamatan Balige Kabupaten Toba Samosir": Universitas Sumatera Utara

Yuni, suryaningtyas. (2016). Hubungan Pemberian ASI Eksklusif dan Perilaku Ibu Dalam Cuci Tangan Pakai Sabun Dengan Kejadian Penyakit Diare Pada Bayi usia 6-12 bulan di Wilayah Kerja Puskesmas Banyudono Kabupaten Boyolali. Publikasi Ilmiah: Universitas Muhammadiyah Surakarta

Yuriulla, Istyaningrum. (2010). "Hubungan Antara Pemberian ASI Eklusif Dengan Kejadian Diare dan Faktor-Faktor Pada Bayi Berusia 6-12 Bulan di Kelurahan Bendung Kecamatan Cilegon": Universitas Islam Negeri Syarif Hidayatullah. Jakarta.

Zuliana, Irma . (2016). Hubungan Antar Perilaku Cuci Tangan Ibu Dengan Kejadian Diare Pada Balita di Desa Leyangan Ungaran Timur Kabupaten Semarang. Artikel penelitian 